\title{
Influence of process parameters on the residual stress state and properties in disc springs made by incremental sheet forming (ISF)
}

\author{
Muhammad Junaid Afzal' (D) - Ramin Hajavifard² • Johannes Buhl' • Frank Walther² • Markus Bambach ${ }^{1,3}$
}

Received: 25 January 2021 / Accepted: 30 April 2021 / Published online: 31 May 2021

(c) The Author(s) 2021

\begin{abstract}
Disc springs are machine elements that are used when high forces need to be supplied and in limited installation space. They need to fulfil high demands on the stability of the spring characteristics, reliability and lifetime. In corrosive environments, metastable austenitic stainless steels (MASS) disc springs are often used. Tensile stresses that occur during service limit the lifetime of disc springs. Usually, their durability is enhanced by generating favorable compressive residual stresses using shot peening operations. Such operations lead to extra efforts and additional production costs. In this study, the adaptive and targeted generation of residual stresses via incremental sheet forming (ISF) is investigated as alternative to shot peening focusing on EN 1.4310 and EN 1.4401 stainless steel. Previous work has shown that ISF is capable of controlling the radial and tangential stresses in the springs. However, no analysis of the influence of the residual stress state in the rolled sheet strips and the ISF process parameters was performed. The goal of the current work is to analyze the evolution of residual stress during rolling and subsequent incremental forming of disc springs. In order to examine the role of dissipation and temperature increases in the rolling process, sheet blanks rolled at room and elevated temperature are analyzed. The characteristics of the compressive residual stresses induced by ISF are studied for different process parameters. X-ray diffraction is used to investigate the buildup of these stresses. Using ISF, the generation of compressive residual stresses can be integrated into the forming process of disc springs, and further post-treatment may be skipped. The results show that the residual stress state in the rolled material is crucial, which requires tight control of the rolling temperature. Another result is that ISF is able to yield high compressive residual stresses and improved spring characteristics when small tool diameters and step-down values are used.
\end{abstract}

Muhammad Junaid Afzal

afzal@b-tu.de

1 Chair of Mechanical Design and Manufacturing $(\mathrm{KuF})$, Brandenburg University of Technology Cottbus-Senftenberg, Konrad-Wachsmann-Allee 17, 03046 Cottbus, Germany
2 Department of Materials Test Engineering (WPT), TU Dortmund University, Baroper Str. 303, 44227 Dortmund, Germany

3 Advance Manufacturing, Department of Mechanical and Process Engineering, ETH Zurich, Technoparkstrasse 1, 8005 Zürich, Switzerland 


\section{Einfluss der Prozessparameter auf den Eigenspannungszustand und die Eigenschaften von Tellerfedern, hergestellt durch inkrementelle Blechumformung (IBU)}

\section{Zusammenfassung}

Tellerfedern sind Maschinenelemente, die bei hohem Kraftbedarf und eingeschränktem Bauraum Verwendung finden. Tellerfedern müssen hohe Anforderungen an die Stabilität der Kennlinien, Zuverlässigkeit und Lebensdauer erfüllen. In korrosiven Umgebungen werden häufig metastabile Tellerfedern aus austenitischen rostfreien Stählen verwendet. Zugspannungen, die während des Betriebs auftreten, begrenzen die Lebensdauer der Tellerfedern. Normalerweise wird ihre Lebensdauer verbessert, indem günstige Druckeigenspannungen mittels Kugelstrahlen erzeugt werden. Kugelstrahlen ist ein zusätzlicher Prozessschritt, der zusätzliche Produktionskosten verursacht. In dieser Studie wird die adaptive und gezielte Erzeugung von Eigenspannungen durch inkrementelle Blechumformung (IBU) als Alternative zum Kugelstrahlen an Edelstahl EN 1.4310 und EN 1.4401 untersucht. Frühere Arbeiten haben gezeigt, dass mittels IBU die radialen und tangentialen Spannungen in den Federn eingestellt werden können. Jedoch wurden der Einfluss des Eigenspannungszustands im gewalzten Vormaterial nicht und der Prozessparameter der IBU nicht im Detail untersucht. Ziel der vorliegenden Arbeit ist es, die Entwicklung der Eigenspannung beim Walzen und der anschließenden inkrementellen Umformung von Tellerfedern zu analysieren. Bei Umgebungs- und leicht erhöhter Temperatur gewalzten Blechen wurde der Dissipationseinfluss, der den Temperaturanstieg im industriellen Walzprozess verursacht, analysiert. Die durch IBU induzierten Druckeigenspannungen werden für verschiedene Prozessparameter mittels Röntgenbeugung untersucht. Die Ergebnisse zeigen, dass der Eigenspannungszustand im gewalzten Material entscheidend für die Eigenschaften in den geformten Tellerfedern ist, was eine strenge Kontrolle der Walztemperatur erfordert. Ein weiteres Ergebnis ist, dass durch IBU mit verkleinertem Werkzeugdurchmesser und geringen Zustellungen höhere Druckeigenspannungen und verbesserte Federeigenschaften erzielt werden können.

\section{Introduction}

Disc springs are an essential part of mechanical engineering, where high spring force is required in a small installation space [1]. In applications dominated by dynamic cyclic loading, discs should have high fatigue strength and show little stress relaxation to avoid degradation and failure during service life. Due to their good combination of high strength, low stress relaxation tendency, high corrosion resistance and ductility, metastable austenitic stainless steels (MASS) are a popular choice for disc springs. MASS are also identified as transformation-induced plasticity (TRIP) steels because either during forming or service life a strain-induced austenite-martensite transformation takes place under deformation. Two variants are usually found in austenitic steels, i.e., austenite phase $(\gamma) \rightarrow \varepsilon$ martensite phase and austenite phase $(\gamma) \rightarrow \alpha$ /-martensite. In essence, the martensite transformation depends on the material's critical free energy. The austenite grains are stable at a higher temperature. At a lower temperature, the martensite exists usually in meta-stable state [2]. The formation of the $\alpha /$-martensite phase is crucial as it improves the material's work hardening. This enhancement in work hardening increases the resistance to further plastic deformation at room temperature and is accompanied by expansion in $\gamma \rightarrow \alpha$, phase transformation [3, 4].

However, the possible use of disc springs is constrained by the buildup of residual tensile stresses during the manufacturing process. In order to create compressive stresses in regions that may show tensile stresses after forming, shot peening operations are typically used. During the shot peening process, tiny metallic balls impact the surface and create compressive residual stresses near the surface. Shot peening of disc springs impedes the nucleation of fatigue cracks [5]. Furthermore, shot peening operations also induce martensite (deformation-induced martensite-DIMT) in MASS disc springs. Scherpereel et al. [6] reported that larger residual compressive stresses are developed in the area where the magnitude of martensite content is highest. Fu et al. [7] studied the properties of $18 \mathrm{CrNiMo} 7-6$ steel after shot peening. He found the maximum compressive stress at a depth of $20 \mu \mathrm{m}$ for the optimized shot-peening process. The effect of shot peening of the AISI $301 \mathrm{LN}$ steel in an annealed and cooled rolled condition is studied by Fragas et al. [8]. They found more extensive plastic deformation and martensite formation in the annealed spec-
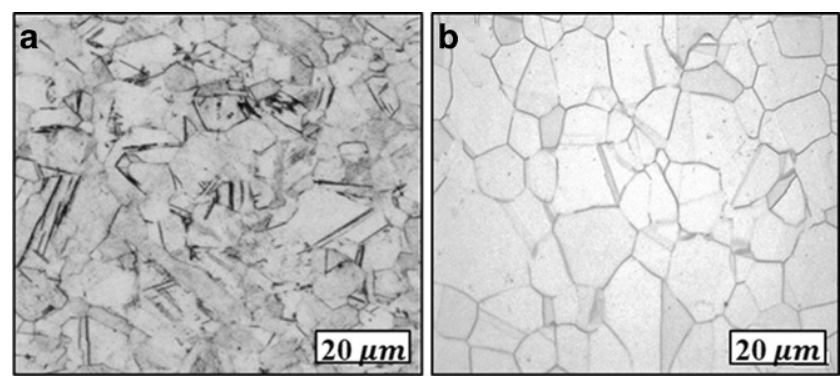

Fig. 1 Optical micrograph of investigated material at initial stage. AISI 301 (a) and AISI 316 (b) 
Table 1 Chemical composition of AISI 301 and AISI 316 steel in weight $\%$ with Fe balance

\begin{tabular}{llllllllll}
\hline Material & $\mathrm{C}$ & $\mathrm{Si}$ & $\mathrm{Mn}$ & $P$ & $\mathrm{~S}$ & $\mathrm{Cr}$ & $\mathrm{Ni}$ & $\mathrm{Mo}$ & $N$ \\
\hline EN 1.4310 & 0.07 & 1.0 & 2.0 & 0.045 & 0.03 & 17.5 & 8.0 & - & 0.1 \\
EN 1.4401 & 0.07 & 1.0 & 2.0 & 0.05 & 0.015 & 16.0 & 6.0 & 0.8 & 0.1 \\
\hline
\end{tabular}

imen compared to cold rolled samples. Furthermore, they also reported the drawbacks of the traditional shot peening method due to its stochastic nature. The result of the process is highly dependent on the selected parameter values [8]. The shot peening operation on one hand increases the residual stress but causes adverse effects on the surface topology i.e. superficial micro cracks, which decreases fatigue life $[9,10]$. Another major drawback of this process is that it is difficult to control the residual stress distribution. Radial residual stresses change the height of the spring [11]. The residual stress in radial direction should hence be minimal and is not possible to control the stress components individually in shot peening. Moreover, shot peening is postproduction process and suitable for the bulk production. For short lot it appeared as an expensive procedure and has limitation especially once this process is required for complex geometries.

Incremental sheet forming (ISF) has been introduced to replace the shot peening process. It is appropriate for economical batch production, in order to promote tangential residual compressive stresses selectively in the disc springs and enhance the industrial manufacturing process. A small hemispherical tool forms a sheet blank locally across a specified path resulting final formed shape during operation. The ISF process is characterized by its localized deformation mechanism, allowing sheet metal to be stretched far beyond the conventional forming limits $[12,13]$. The ISF process has two main variants, i.e., single point incremental forming (SPIF) and two-point incremental forming (TPIF). The localized forming process results in high residual stresses. The evolution of this residual stress in ISF is investigated in several studies $[14,15]$. Due to its adverse effect on geometrical accuracy, techniques like stress relief annealing are used to minimize the residual stress in ISF $[16,17]$. Maaß et al. [18] have investigated the aluminum alloy 5083 and formed linear grooves by the multiple-stage process. They measured the residual stress state via X-ray diffraction in a complex shape component and concluded that the effect of tool step down is unincisive. They detect a relationship between the parameters of the forming process, the residual stresses, and mechanical characteristics of an incrementally formed part [19]. Katajarinne et al. [20] established a progressive method for adjusting material properties, including ductility and strength for the parts produced by incrementally shaping metal sheets. They controlled properties by controlling the martensitic transformation induced by deformation. They also investigated the dependence of the martensitic transformation in MASS on the ISF process parameters. Turski et al. [21] adopted different surface treatment process parameters and studied the residual stresses evolution in the sub-surface of AISI 301LN and AISI 316L steel components. They investigated that $301 \mathrm{LN}$ showed $100 \%$ martensite transformation at a maximum $60^{\circ}$ forming angle. For the 316L grade, only $20 \%$ transformation is measured for the respective conditions. Further, the higher rates of formation are converted into an increase in temperature. This increase in temperature suppresses the transformed fraction.

Two strategies for the targeted generation of residual stresses in MASS disc springs by ISF were proposed in previous studies [12, 22, 23]. The effect of the ISF process parameters, i.e., the forming tool diameter, feed rate, and step-down, on the generated residual stresses are investigated in detail using X-ray diffraction. The role of residual stresses present in the material prior to ISF was not studied in the past. The present study aims at elucidating the role of residual stresses present in MASS after the rolling operation, i.e., whether the capability of controlling the residual stresses using ISF is affected by prior residual stresses.

\section{Materials and methods}

\subsection{Material and geometry of springs}

Disc springs of austenitic steels EN 1.4310 (AISI 301) and EN 1.4401 (AISI 316) were produced by ISF from sheet blanks. Before manufacturing the disc springs using ISF, the initial material was fully annealed followed by subsequent cold and warm rolling. The steel sheets were bought from a commercial steel supplier with an initial thickness of $1.5 \mathrm{~mm}$. The initial microstructure of EN 1.4310 and

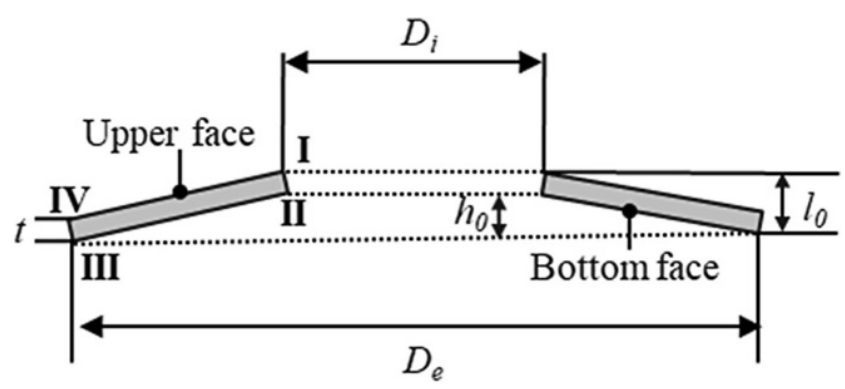

Fig. 2 Sketch of a typical disc spring 
Table 2 Roll temperature and number of rolling passes

\begin{tabular}{lll}
\hline Materials & Rolling temperature & No. of passes \\
\hline$E N 1.4310$ & Room (RT), $80^{\circ} \mathrm{C}, 300^{\circ} \mathrm{C}$ & $3,2,1$ \\
EN 1.4401 & Room (RT), $80^{\circ} \mathrm{C}, 300^{\circ} \mathrm{C}$ & $2,2,1$ \\
\hline
\end{tabular}

EN 1.4401 are presented in Fig. 1. Before the annealing process, the initial fraction of martensite was measured. 15.2\% martensite was found in EN 1.4310 and almost 3\% in EN 1.4401.

The chemical composition of the EN 1.4310 and EN 1.4401 are presented in Table 1. A final sheet thickness of $1 \mathrm{~mm}$ is attained via flat rolling as described in Sect. 2.3 below. DIN 2092 [24] is adopted for the manufacturing of the final disc springs. The typical disc spring sketch is shown in Fig. 2. The terms $D_{e}, D_{i}, t$, and $l_{o}$ represent the external diameter, internal diameter, thickness, and free height of the disc springs, respectively.

The geometry chosen for the EN 1.4310 and EN 1.4401 for forming by ISF is $120 / 57 / 1 \mathrm{~mm}\left(\mathrm{D}_{\mathrm{e}} / \mathrm{D}_{\mathrm{i}} / \mathrm{t}\right)$. The mechanical responses are compared with conventionally formed disc springs produced by a commercial supplier. The residual stresses are studied using X-ray diffraction (XRD) in the disc springs made of the rolled sheets. The investigation of two different materials helps to differentiate the role of phase transformation and plastic deformation on residual stress. Therefore, by comparing the findings from these two materials, the role of the martensitic transformation on residual stresses will be analyzed.

\subsection{Annealing}

Both material grades were in a spring hard state initially. A heat treatment process (annealing) was conducted using a heat treatment furnace with a maximum temperature of $1250^{\circ} \mathrm{C}$. Both steels, the EN 1.4310 and EN 1.4401 were heated to a temperature about 1060 and $1090^{\circ} \mathrm{C}$, respectively, and then held at these temperatures for $5 \mathrm{~min}$ [25] before being cooled slowly in air.

\subsection{Rolling process}

The subsequent rolling of the sheet blanks was performed after the full annealing process. The initial dimension of the sheet's blanks taken for EN 1.4310 and EN 1.4401 are of length $(l)=155 \mathrm{~mm}$, width $(w)=155 \mathrm{~mm}$ and thickness $(t)=1.5 \mathrm{~mm}$. The sheet blank was drawn by friction through opening of the rotating rollers to achieve the reduction in the thickness. Multi-pass rolling is applied to achieve the final thickness of $1 \mathrm{~mm}$. The rolling process is divided into two categories, the rolling in the cold state and with slightly elevated temperatures. The rolling temperatures and the number of passes are listed in Table 2. The desired rolling process was carried out utilizing a rolling mill manufactured by Carl Wezel GmbH, Germany having a maximum force capacity of $1600 \mathrm{kN}$, a roll diameter of $330 \mathrm{~mm}$, a roll width of $800 \mathrm{~mm}$, and a rolling speed of $30 \mathrm{~m} / \mathrm{min}$, see Fig. 3 .

\subsection{Incremental sheet metal forming}

During the ISF operation, the sheet blanks are deformed locally by a small hemispherical tool along the designated path. Hajavifard et al. [23] and Maqbool et al. [22] concluded in their work that TPIF with a negative die is the best-suited variant for the forming of disc springs.

Fig. 4 presents the experimental set-up of the TPIF variant with a negative die and the complete process chain of ISF disc spring manufacturing using the rolled sheet blanks. The disc springs were manufactured using ISF from rolled sheet blanks of EN 1.4310 and EN 1.4401 employing an industrial robot from $\mathrm{ABB}$ and a hemispherical forming tool. Sika ${ }^{\circledR}$ inserts are used as exchangeable negative dies in a steel casing. A plastic deformation caused by the hemispherical tool forms the clamped sheet into the disc spring. The disc springs made of EN 1.4310 and EN 1.4401 steels were produced with variation in tool diameters, tool stepdowns, contact forces as well as feed rates (see Table 3). Once the disc springs are formed, trimmings are made by wire-cutting to achieve the desired geometry.
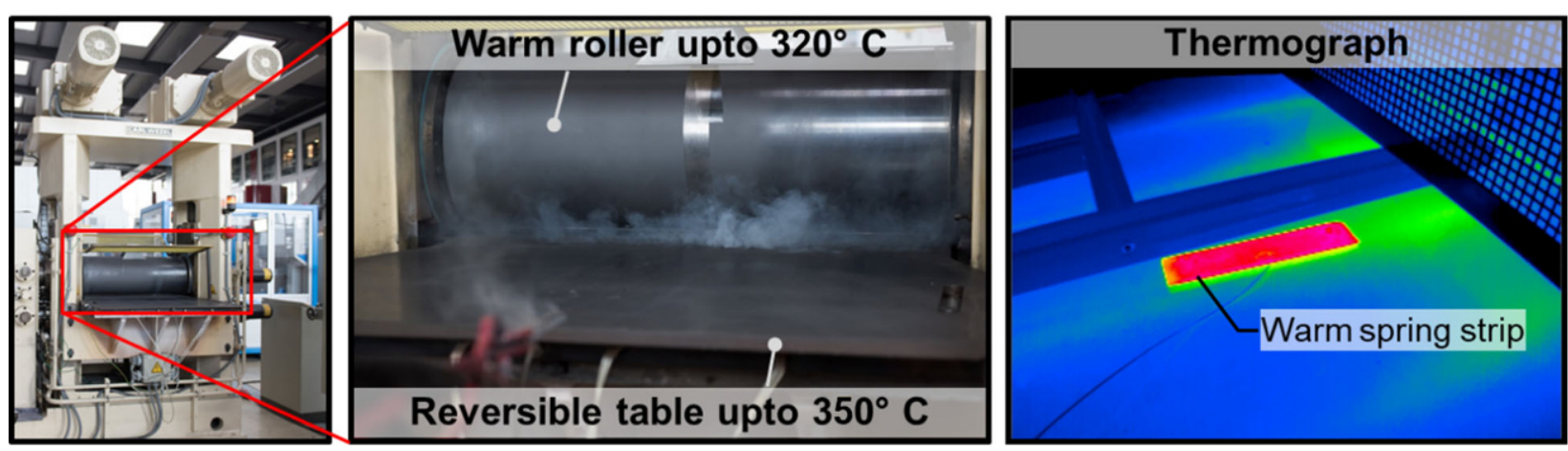

Fig. 3 Rolling mill setup utilized for flat rolling experiments with elevated temperature 


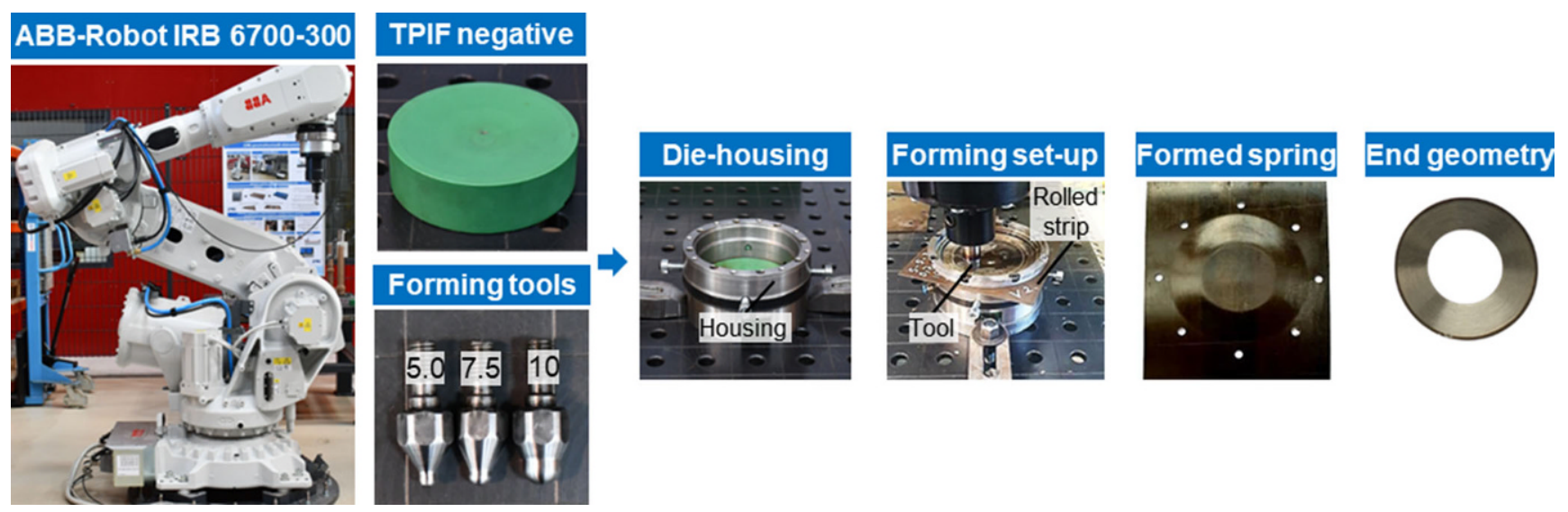

Fig. 4 Experimental set-up of the complete process chain for the manufacturing of disc spring with TPIF using ABB-Robot arm

\subsection{Material characterization and microstructural analysis}

Optical microscopy: The microstructural analyses of both sheets of EN 1.4310 and EN 1.4401 were conducted after the sheet blanks were rolled under different rolling temperatures. Micro-sections were taken and etched with V2Aetchant for $40 \mathrm{sec}$. The investigations were carried out on the surface layer of the sheet blanks, which were in contact with rollers, to inspect the influence on the martensite formation on residual stress characteristics of the rolled sheets and disc springs. For the micrographic analysis, a VHX7000 digital microscope by Keyence, Germany is used.

Tensile test: For material characterization, tensile tests are performed along the rolling direction for a strain rate of $0.01 \mathrm{~s}^{-1}$ at room temperature for sheet blanks of steels EN 1.4310 and EN 1.4401. The tensile tests are carried out by the using dilatometer DIL805. The dimension of the tensile specimen is presented in Fig. 5.

\subsection{Residual stress measurement}

The residual stress measurements were performed in the rolling direction of the sheet blanks and the tangential direction of the disc springs. The Bruker D8 Discover x-ray diffractometer (XRD) was employed for the measurement. This system works based on the $\sin ^{2} \Psi$ method. Analyses were performed at five measurement angles $[0 ; 11.25$; $22.5 ; 37.75 ; 45]$ applying $\mathrm{Cu}$ radiation with a voltage of $40 \mathrm{kV}$ and a current of $40 \mathrm{~mA}$ (see Table 4). The range of $2 \theta$ was from 112 up to $123^{\circ}$ with a diffraction peak at $118.194^{\circ}$. Thus, the diffraction plane was $\{400\}$. The step width was $0.1^{\circ}$ with a measurement time of 20 s per measurement point. The collimator diameter was $2 \mathrm{~mm}$ and the Azimuth positions $\varphi$ were 90 and $270^{\circ}$. (Fig. 6).

\subsection{Quasi-static testing}

A servo-hydraulic system $(\mathrm{F}= \pm 10 \mathrm{kN})$ was used for mechanical testing. For clamping under suitable boundary conditions, a fixture was manufactured and attached to the testing equipment. The experimental set-up is depicted in Fig. 7. Using various test parameters, quasi-static tests of conventionally and incrementally formed disc springs are performed by compressing them in a flattened state with deflection rate of $0.0025 \mathrm{~s}^{-1}$. The resulting force-displacement curve was recorded. An extensometer with a gauge length of $12.5 \mathrm{~mm}$ was used for deflection measurements. As a result, the influence of various ISF process parameters on force-deflection characteristics of conventionally and incrementally formed disc springs made of rolled sheet metal can be compared.

\section{Results and discussion}

\subsection{Microstructure and material characterization}

The micrographs are used to determine the influence of the rolling temperature on martensite formation. Both steel sheets were annealed before rolling. Fig. 8a, b shows the

Table 3 Various ISF parameters

\begin{tabular}{llllll}
\hline Materials & Disc dimension $\left(\mathrm{D}_{\mathrm{e}} / \mathrm{D}_{\mathrm{i}} / \mathrm{t}\right)$ & Forming tool $(\mathrm{mm})$ & Tool step down & Contact force $(\mathrm{N})$ & Feed rate $(\mathrm{mm} / \mathrm{s})$ \\
\hline$E N ~ 1.4310$ & $120 / 57 / 1 \mathrm{~mm}$ & 5,10 & $0.05,0.1,0.2$ & $750,1000,1500$ & $80,150,250$ \\
EN 1.4401 & $120 / 57 / 1 \mathrm{~mm}$ & & & & \\
\hline
\end{tabular}




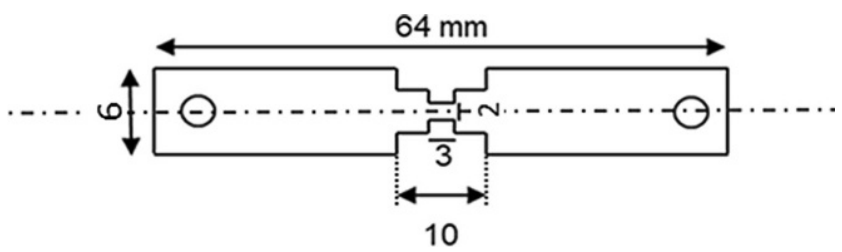

Fig. 5 Geometry of tensile specimen

microstructure of steel sheets EN 1.4310 and EN 1.4401 after annealing. The grains are in an undeformed state after the annealing process and their sizes range vary from small micron $(0.25 \mu \mathrm{m})$ to large $(21 \mu \mathrm{m})$ in case of EN 1.4310 . For EN 1.4401 the variation is in between $2.5 \mu \mathrm{m}$ to $80 \mu \mathrm{m}$.

The micrographs of EN 1.4310 and EN 1.4401 after rolling are shown in Fig. 9a-f. The micrograph of EN 1.4310 rolled at RT shows a significant amount of the deformation-induced martensite transformation (DIMT); see Fig. 9a. In addition, retained austenite embedded in the martensite matrix results in martensite-austenite islands. Fig. 9b, c shows that an increase in rolling temperature reduces the martensitic transformation. The least martensite formation is observed for the highest rolling temperature. However, in the case of EN 1.4401, Fig. 9d-f, the austenitic phase appeared to be prominent and DIMT can be seen. From the micrographs, it is concluded that steel EN 1.4310 is more susceptible to DIMT at room temperature.

Mechanical properties of rolled sheets were also studied using the uniaxial tensile tests. Fig. 10 presents the typical stress-strain curve along the rolling direction, at a strain rate of $0.01 \mathrm{~s}^{-1}$ for rolled EN 1.4310 and EN 1.4401 at various deformation conditions. The stress-strain curves of EN 1.4310 are anisotropic and show substantial work hardening due to the formation of martensite during straining (Fig. 10a). Contrary to this EN 1.4401 showed an isotropic behavior and depicted lower yield strength and work hardening compared to EN 1.4310, Fig. 10b. Furthermore, the yield points of the cold rolled specimens are comparatively higher than for the material rolled at elevated temperature. The yield strength of the materials decreases with increasing rolling temperature resulting in increased ductility. Larger fracture strains are observed in all—specimen rolled at elevated temperature.

\subsection{Residual stress measurement}

After the rolling operation, the residual stress magnitudes are measured to quantify the role of the martensite development and plastic deformation on residual stress formation. Fig. 11a shows the residual stress development for EN 1.4310 along rolling direction. The residual stress values calculated from the XRD measurements is highest in the cold rolled sheet of EN 1.4310, which means that deformation induced martensitic transformation during rolling increases the residual stresses. Furthermore, the residual stress values decrease with increasing rolling temperature. In EN 1.4401, Fig. 1b, the similar stress drop is observed. However, the residual stresses of samples rolled at $300^{\circ} \mathrm{C}$ is similar for EN 1.4310 and EN 1.4401. This is a result of the almost negligible formation of martensite. It can be concluded here the development of residual stress in EN 1.4310 is due to martensite transformation and residual stresses induced by plastic deformation of the austenite during rolling, whereas in EN 1.4401, predominantly the plastic deformation of the austenite seems to contribute to residual stress formation.

To analyze the influence of martensite on the generation of residual stresses in EN 1.4310, the ferromagnetic content was examined at three distinct points located on the surface of the rolled sheets by a Feritscope. Fig. 12 shows the measured points along the total volume of martensite. The martensite content is calculated based on the relationship between ferrite and martensite content determined by Talonen et al. [26].

Fig. 13a, b presents the residual stress magnitudes of the incrementally formed disc springs manufactured from sheet blanks with different microstructure and residual stress properties. The residual stresses are measured on the bottom face of the disc springs. The difference in the residual stress properties is prominent with constant ISF parameters. The highest residual stress is calculated for both sheets of steel rolled at room temperature. It is also observed that the difference between the residual stress magnitudes of EN 1.4310 and EN. 14401 rolled at $300{ }^{\circ} \mathrm{C}$ differ, since DIMT is more dominant in EN 1.4310. The forming tool diameter has a noticeable impact on the development of these compressive stresses. It is found that the smaller tool diameter and higher contact force contribute more to plastic strain and leads to more localized

Table 4 XRD measurement parameters used for residual stress analyses

\begin{tabular}{llllll}
\hline Parameters & Unit & Values & Parameters & Unit & Values \\
\hline Target & - & $\mathrm{Cu}$ & Young's modulus & $\mathrm{GPa}$ & 220 \\
Wavelength $\mathrm{k}_{\alpha 1}$ & $\AA$ & 0.1540549 & Poisson ratio & - & 0.28 \\
Diffraction plane $\{\mathrm{hkl}\}$ & - & $\mathrm{Fe}-\alpha\{400\}$ & Collimator $\varnothing$ & $\mathrm{Mm}$ & 2 \\
Current & $\mathrm{mA}$ & 40 & $\theta$-angle & $\circ$ & $(0 ; 11.25 ; 22.5 ; 37.75 ; 45)$ \\
Voltage & $\mathrm{kV}$ & 40 & $\varphi$-angle & $\circ$ & $(90 ; 270)$ \\
\hline
\end{tabular}


Fig. 6 Set-up for the X-ray measurements

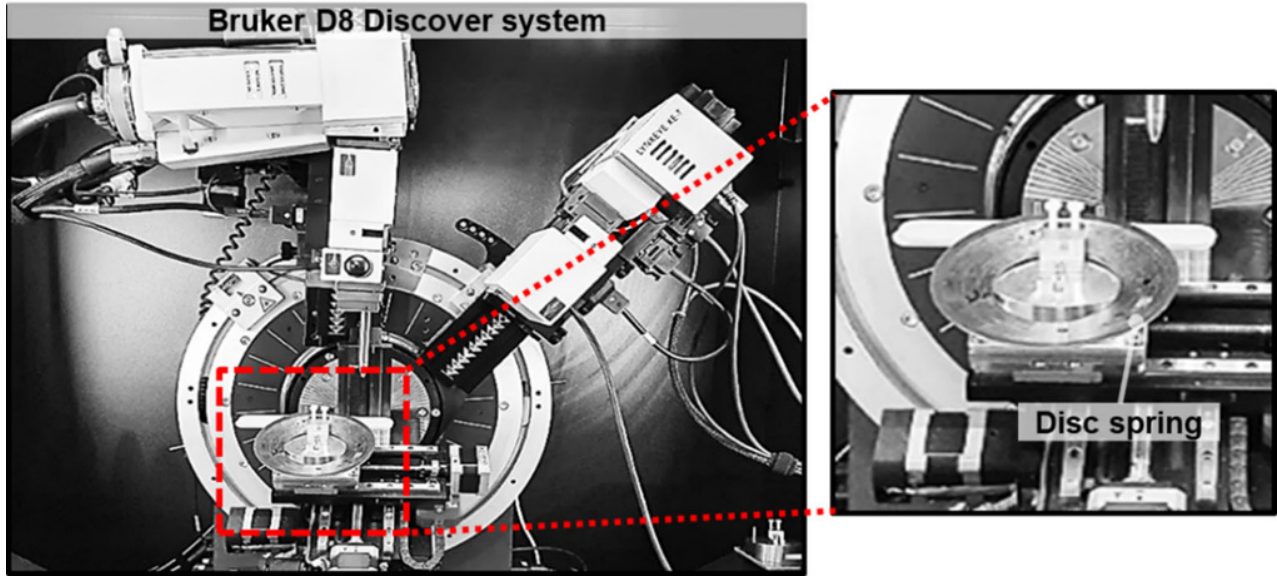

deformation, Fig. 13c. Furthermore, the compressive residual stresses of the incrementally formed disc springs are significantly higher than those formed by conventional approaches (Fig. 13d). The presented compressions with conventional disc springs are neither shot-peened nor surface-treated. This means that ISF can be used to induce and targeted adjust the residual stresses at the same time of the disc spring manufacturing.

Fig. 14a-c shows the development of residual stresses with the variation of tool step down, contact force, and feed rate. A significant fluctuation in the developed residual stresses can be observed. With increasing tool step down, the induced residual stresses magnitude is decreased, Fig. 14a. The contact force tends to raise the residual stresses, Fig. 14c. However, variations in feed rate show no substantial effect on the residual stresses. This indicates that the ISF process is able to induce the desired residual stresses.

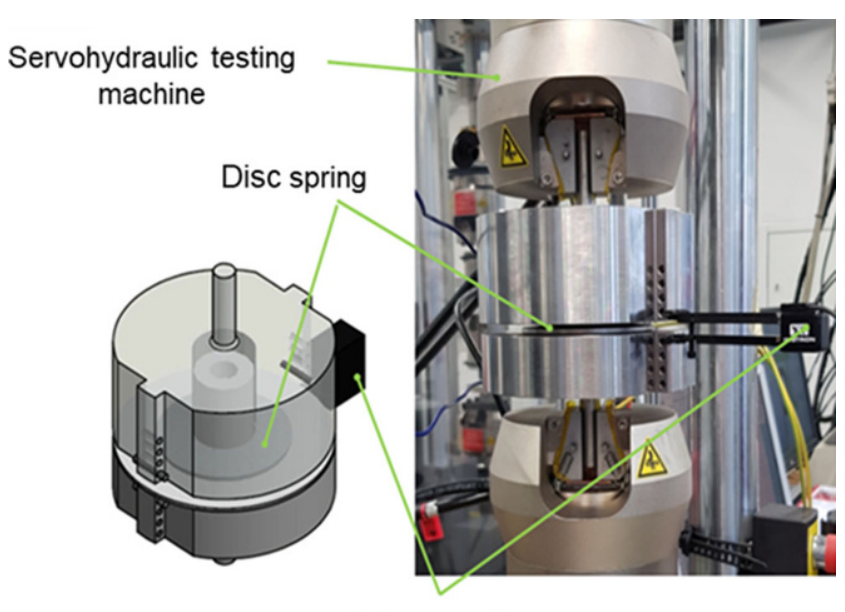

Extensometer

Fig. 7 Experimental set-up for quasi-static testing of disc springs
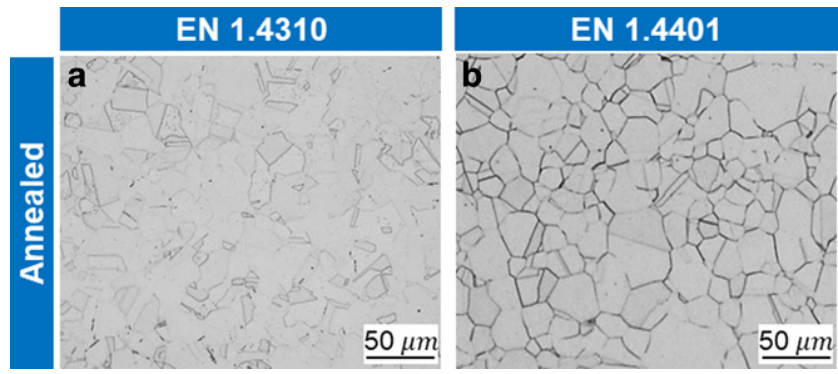

Fig. 8 Micrograph of EN 1.4310 (a) and EN 1.4401 (b) after annealing

\subsection{Quasi-static testing}

The quasi-static compression tests were carried out using the designed experimental setup by flattening conventional and ISF disc springs produced from sheet rolled at different temperatures. A significant enhancement of the spring deflection capacity was observed for the incrementally formed disc springs in mechanical disc compression tests (Fig. 15a, b). Furthermore, the effect of the prior forming operation can be identified. The measured residual stresses for the given spring forces are shown in Fig. 13a, b. Here, it is important to mention that the conventional disc used for the comparison were not shot peened.

The highest spring force is reached by the disc spring formed from sheet blanks of EN 1.4310 rolled at room temperature, due to the significant martensitic transformation and the targeted residual stress produced by the hemispherical tool during ISF. The effects of the process parameters on the stresses caused by ISF are observed.

\section{Conclusions}

Previous research indicates that ISF can regulate radial and tangential stresses in the springs. However, no study on 

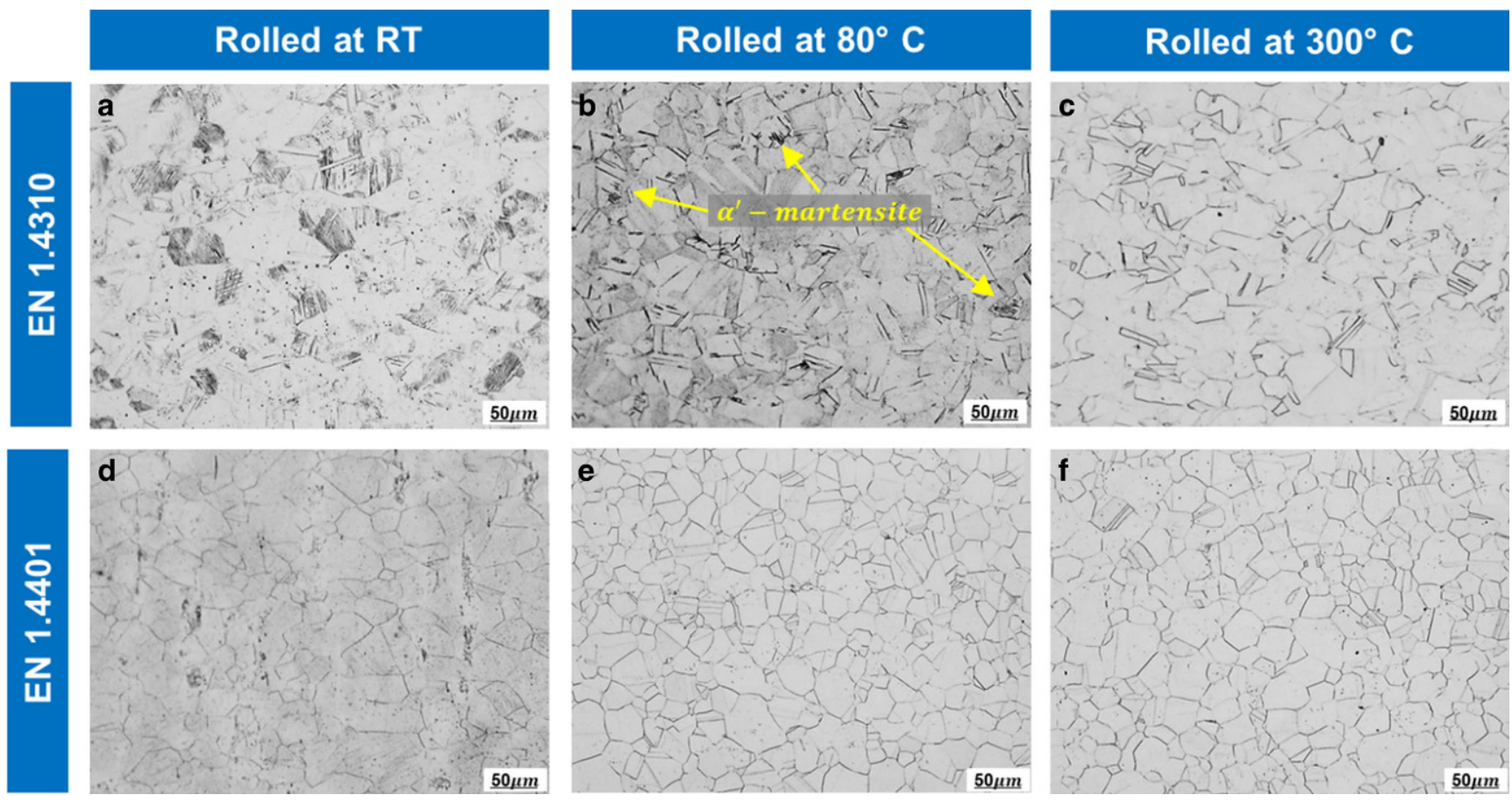

Fig. 9 Micrographs of EN 1.4310 (a-c) and EN $1.4401(\mathbf{d}-\mathbf{f})$ after rolling at various temperatures

Fig. 10 Stress-strain curves of EN 1.4310 (a) and EN 1.4401 (b) after rolling at RT, $80^{\circ} \mathrm{C}$, and $300^{\circ}$

Fig. 11 X-ray analysis of the rolled sheet blanks: EN 1.4310 (a) and EN 1.4401 (b) before the ISF operation
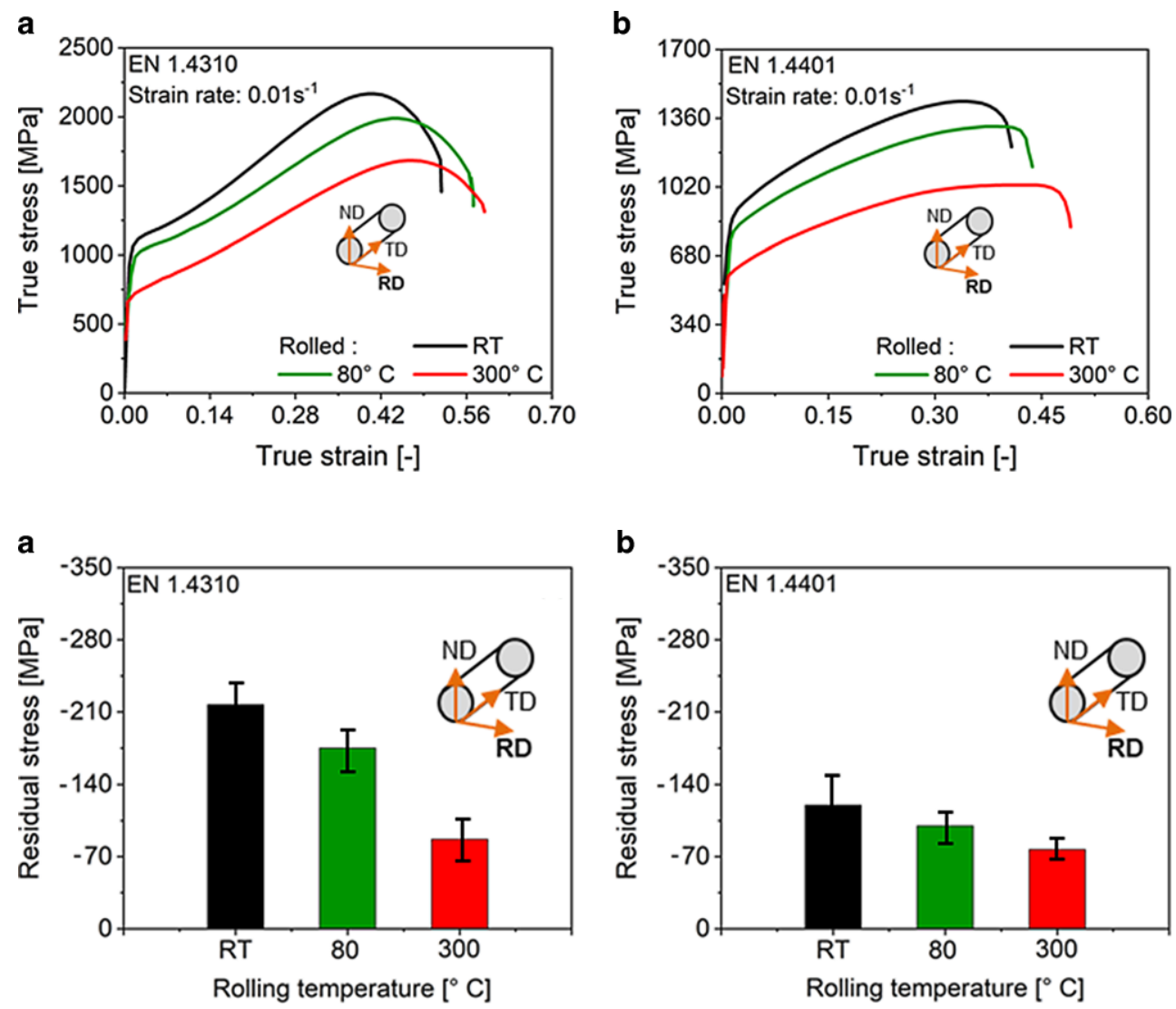
Fig. 12 Experimentally measured ferromagnetic content at three points on the surface of the rolled sheets of EN 1.4310

Fig. 13 Compressive residual stress magnitudes of incrementally formed disc springs at three rolling temperatures for EN 1.4310 (a), and for EN 1.4401 (b). Comparison of different tool diameters (c) and different forming strategies (d)
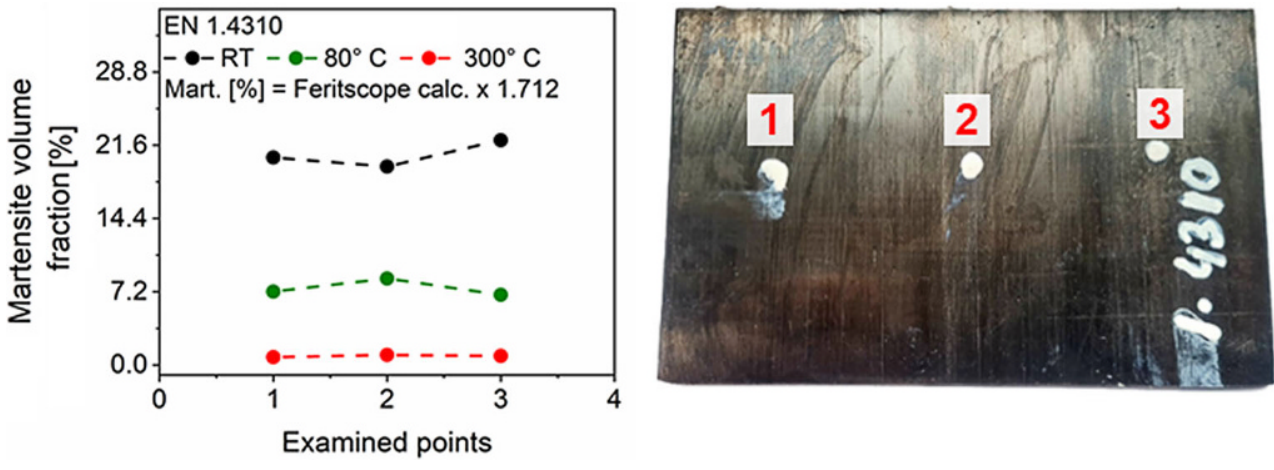

a

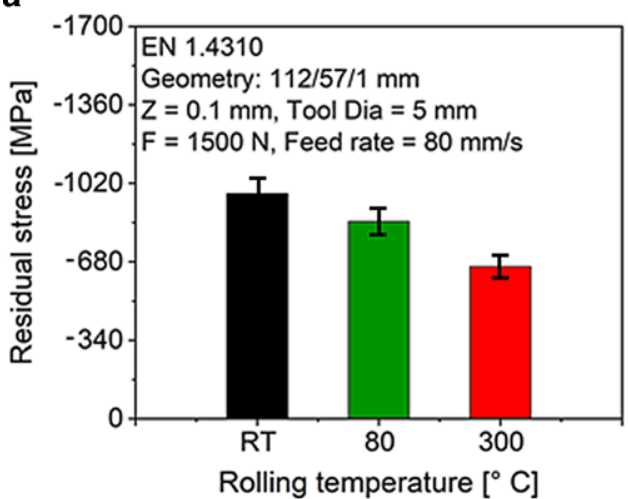

C

Rolling temperature $\left[{ }^{\circ} \mathrm{C}\right]$

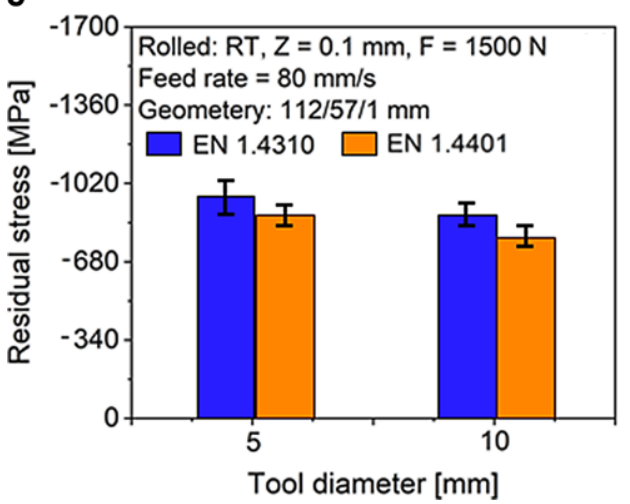

b

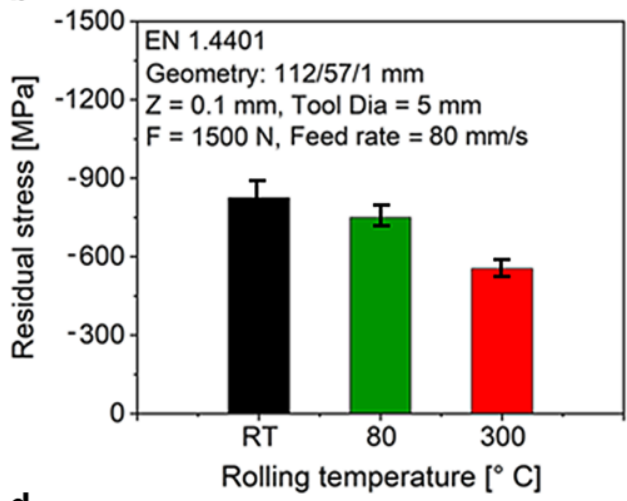

d

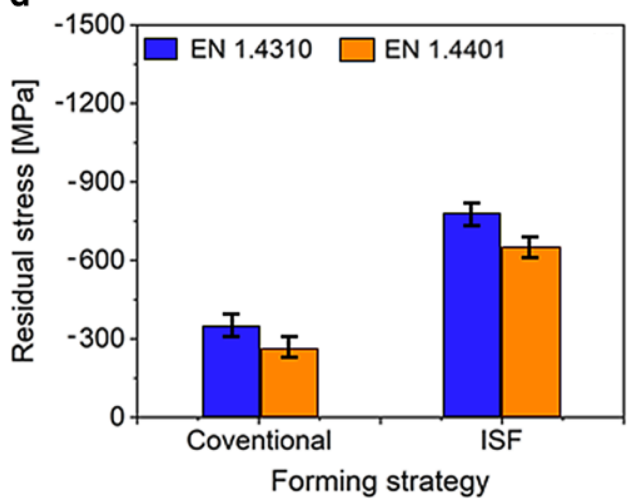

the impact of residual stress conditions in the rolled sheet strips was done with elevated temperatures. The aim of the analysis is to examine residual stress during rolling and its consequent effects on the forming of disc springs. Disc springs were carried out with a negative die on a TPIF setup. The results of the process parameters on the stresses caused by ISF were observed. The findings demonstrate the significance of close regulation of the rolling temperature, and that ISF is able to yield strong compressive residual stresses and better spring characteristics when smaller tool diameters and step-down values are used. The following conclusions can be drawn from the investigations:

- A considerable build-up of martensite is observed in the rolled sheet of EN 1.4310 produced at room temperature.
Rolling at elevated temperatures decrease the martensite contents and residual stresses.

- EN 1.4401 does not develop martensite after rolling and ISF. Even though the generation of residual stresses depends on plastic deformation of the austenite, the same tendency is observed as with EN 1.4310, i.e., the largest residual stresses are observed when the steel is cold rolled. This shows that temperature control in rolling (active cooling to counteract the effects of dissipation and friction) is vital in order to achieve reproducible residual stress states.

- The highest compressive residual stresses are found in EN 1.4310 and EN 1.4401, when cold rolled sheet is incrementally formed. Residual stresses in formed disc 
Fig. 14 Compressive residual stress magnitudes at various tool step downs (a), contact force (b), and feed rate $(\mathbf{c})$
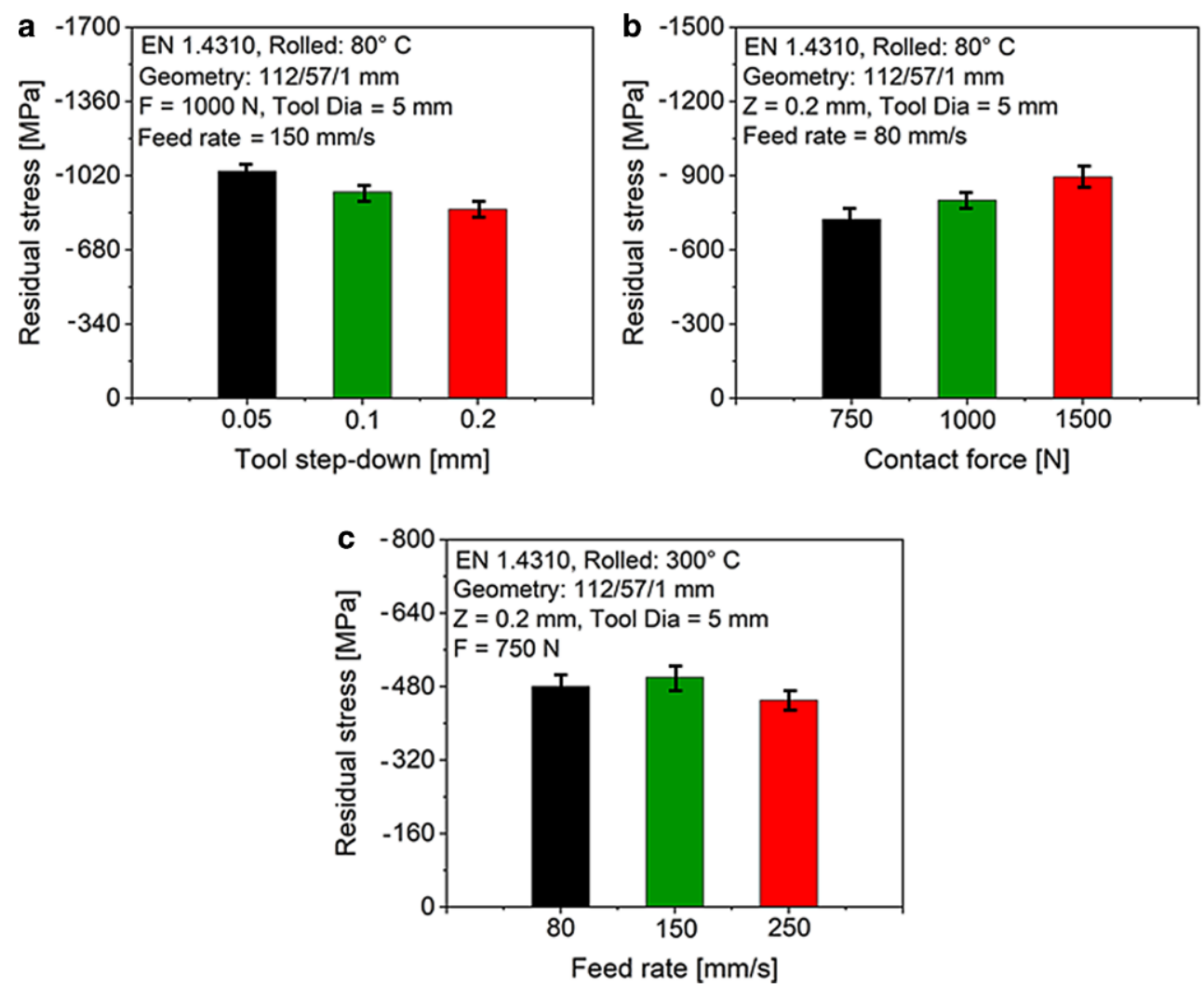

Fig. 15 Characteristic forcedeflection curves of conventionally and incrementally formed disc springs formed from different sheet blanks with the same ISF process parameters, EN 1.4310 (a) and EN 1.4401 (b)

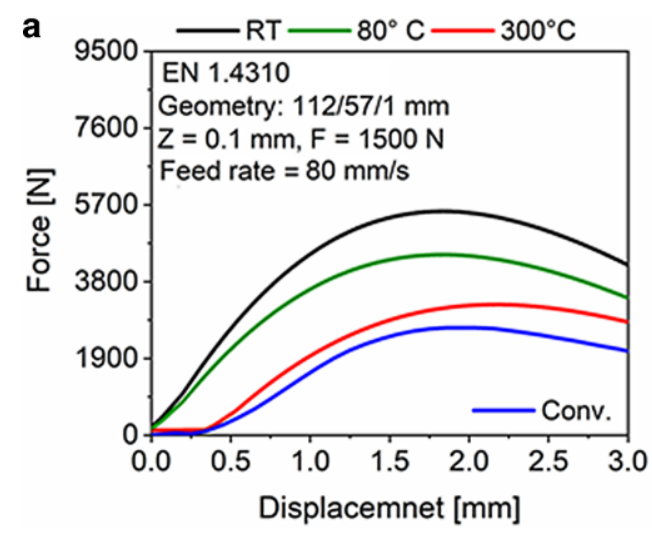

springs are less by rolling at elevated temperature in both materials EN 1.4310 and EN 1.4401.

- A smaller tool diameter could induce a more residual stresses compared to a larger tool diameter. Increasing the tool step down resulted in a decrease in residual stress induction. The variation of the feed rate had no significant effect on the residual stress properties of the springs.

- The residual stress analyses and force-deflection tests indicate that incrementally formed springs have better spring characteristics than the conventionally formed ones and ISF process improves the magnitude of the induced residual compressive stresses.
However, it is essential to analyze the stability of the residual stresses under service conditions. The cyclic testing will be conducted on the manufactured disc springs to describe the effect of the prior forming process, i.e., rolling, on the fatigue life.

Acknowledgements The authors gratefully acknowledge the German Research Foundation (Deutsche Forschungsgemeinschaft, DFG) for the support of the research "Selective induction and stabilization of residual stresses in austenitic disc springs by incremental forming and integrated surface layer treatment" within the priority program 'SPP 2013' through project no. 'BA 4253/6-2' and 'WA 1672/31-2'. The authors also thank the German Research Foundation and the Ministry of Culture and Science of North Rhine-Westphalia (Ministerium für Kultur und Wissenschaft des Landes Nordrhein-Westfalen, MKW 
NRW) for their financial support within the Major Research Instrumentation Program (X-ray diffractometer, INST 212/399-1 FUGG).

Funding Open Access funding enabled and organized by Projekt DEAL.

Conflict of interest M.J. Afzal, R. Hajavifard, J. Buhl, F. Walther and $\mathrm{M}$. Bambach declare that they have no competing interests.

Open Access This article is licensed under a Creative Commons Attribution 4.0 International License, which permits use, sharing, adaptation, distribution and reproduction in any medium or format, as long as you give appropriate credit to the original author(s) and the source, provide a link to the Creative Commons licence, and indicate if changes were made. The images or other third party material in this article are included in the article's Creative Commons licence, unless indicated otherwise in a credit line to the material. If material is not included in the article's Creative Commons licence and your intended use is not permitted by statutory regulation or exceeds the permitted use, you will need to obtain permission directly from the copyright holder. To view a copy of this licence, visit http://creativecommons.org/licenses/by/4. $0 \%$.

\section{References}

1. Curtze S, Kuokkala V-T, Hokka M et al (2009) Deformation behavior of TRIP and DP steels in tension at different temperatures over a wide range of strain rates. Mater Sci Eng A 507:124-131. https:// doi.org/10.1016/j.msea.2008.11.050

2. Oberg E (2016) Machinery's handbook: a reference book for the mechanical engineer, designer, manufacturing engineer, draftsman, toolmaker, and machinist, 30th edn. Industrial Press, South Norwalk

3. Olson GB, Cohen M (1972) A mechanism for the strain-induced nucleation of martensitic transformations. J Less Common Met 28:107-118. https://doi.org/10.1016/0022-5088(72)90173-7

4. Fahr D (1971) Stress- and strain-induced formation of martensite and its effects on strength and ductility of metastable austenitic stainless steels. Metall Trans 2:1883-1892. https://doi.org/10.1007/ BF02913420

5. Holweger W, Walther F, Loos J et al (2012) Non-destructive subsurface damage monitoring in bearings failure mode using fractal dimension analysis. Ind Lubr Tribol 64:132-137. https://doi.org/10. 1108/00368791211218650

6. Peyre P, Scherpereel X, Berthe L et al (2000) Surface modifications induced in $316 \mathrm{~L}$ steel by laser peening and shot-peening. Influence on pitting corrosion resistance. Mater Sci Eng A 280:294-302. https://doi.org/10.1016/S0921-5093(99)00698-X

7. Fu P, Zhan K, Jiang C (2013) Micro-structure and surface layer properties of $18 \mathrm{CrNiMo7}-6$ steel after multistep shot peening. Mater Des 51:309-314. https://doi.org/10.1016/j.matdes.2013.04. 011

8. Fargas G, Roa JJ, Mateo A (2015) Effect of shot peening on metastable austenitic stainless steels. Mater Sci Eng A 641:290-296. https://doi.org/10.1016/j.msea.2015.05.079

9. Fathallah R (2004) High cycle fatigue behavior prediction of shotpeened parts. Int J Fatigue 26:1053-1067. https://doi.org/10.1016/ j.ijfatigue.2004.03.007

10. Guagliano M, Vergani L (2004) An approach for prediction of fatigue strength of shot peened components. Eng Fract Mech 71:501-512. https://doi.org/10.1016/S0013-7944(03)00017-1
11. Doman Y (2003) Influence of residual stress on the load-deflection curve of diaphragm springs for automobile clutches. JSAE Rev 24:197-203. https://doi.org/10.1016/S0389-4304(02)00299-0

12. Maqbool F, Hajavifard R, Walther F et al (2019) Engineering the residual stress state of the metastable austenitic stainless steel (MASS) disc springs by incremental sheet forming (ISF). Prod Eng Res Dev 13:139-148. https://doi.org/10.1007/s11740-018-0864-6

13. Emmens WC, van den Boogaard AH (2009) An overview of stabilizing deformation mechanisms in incremental sheet forming. J Mater Process Technol 209:3688-3695. https://doi.org/10.1016/j. jmatprotec.2008.10.003

14. Shi X, Hussain G, Butt SI et al (2017) The state of residual stresses in the $\mathrm{Cu}$ /steel bonded laminates after ISF deformation: an experimental analysis. J Manuf Process 30:14-26. https://doi.org/10. 1016/j.jmapro.2017.09.009

15. Radu C, Tampu C, Cristea I et al (2013) The effect of residual stresses on the accuracy of parts processed by SPIF. Mater Manuf Process 28:572-576. https://doi.org/10.1080/10426914. 2013.763967

16. Maqbool F, Bambach M (2017) A modular tooling set-up for incremental sheet forming (ISF) with subsequent stress-relief annealing under partial constraints. AIP Conf Proc. https://doi.org/10.1063/1. 5008090

17. Behera AK, Ou H (2016) Effect of stress relieving heat treatment on surface topography and dimensional accuracy of incrementally formed grade 1 titanium sheet parts. Int $\mathbf{J}$ Adv Manuf Technol 87:3233-3248. https://doi.org/10.1007/s00170-016-8610-8

18. Maaß F, Hahn M, Dobecki M et al (2019) Influence of tool path strategies on the residual stress development in single point incremental forming. Procedia Manuf 29:53-58. https://doi.org/10.1016/ j.promfg.2019.02.105

19. Maaß F, Hahn M, Tekkaya AE (2020) Interaction of process parameters, forming mechanisms, and residual stresses in single point incremental forming. Metals 10:656. https://doi.org/10.3390/ met 10050656

20. Katajarinne T, Louhenkilpi S, Kivivuori S (2014) A novel approach to control the properties of austenitic stainless steels in incremental forming. Mater Sci Eng A 604:23-26. https://doi.org/10.1016/j. msea.2014.03.020

21. Turski M, Clitheroe S, Evans AD et al (2010) Engineering the residual stress state and microstructure of stainless steel with mechanical surface treatments. Appl Phys A 99:549-556. https://doi.org/10. 1007/s00339-010-5672-6

22. Maqbool F, Hajavifard R, Walther F et al (2019) Experimental investigation and finite element modelling of residual stress control in disc springs made of metastable austenitic stainless steel (MASS) using incremental sheet forming (ISF). Procedia Manuf 29:12-20. https://doi.org/10.1016/j.promfg.2019.02.099

23. Hajavifard R, Maqbool F, Schmiedt-Kalenborn A et al (2019) Integrated forming and surface engineering of disc springs by inducing residual stresses by incremental sheet forming. Materials. https:// doi.org/10.3390/ma12101646

24. DIN EN 2092:2006-10, Luft- und Raumfahrt- Aluminiumlegierung AL-P7075-T6, 2092:2005

25. Peckner D (1977) Handbook of stainless steels. McGraw-Hill, New York, London

26. Talonen J, Hänninen $H$, Nenonen $P$ et al (2005) Effect of strain rate on the strain-induced $\gamma \rightarrow \alpha^{\prime}$-martensite transformation and mechanical properties of austenitic stainless steels. Metall Trans 36:421-432. https://doi.org/10.1007/s11661-005-0313-y 